KEMAS 12 (1) (2016) 76-89
Jurnal Kesehatan Masyarakat

\title{
THE ROLE OF PUBLIC HEALTH CENTERS (PUSKESMAS) AS THE GATEKEEPER OF NATIONAL HEALTH INSURANCE
}

\author{
Betri Anita $^{\bowtie}$, Henni Febriawati, Yandrizal \\ Faculty of Health Sciences, University of Muhammadiyah Bengkulu
}

\begin{tabular}{l} 
Article Info \\
\hline Article History: \\
Submited September 2016 \\
Accepted June 2016 \\
Published July 2016 \\
\hline Keywords: \\
Management; Commu- \\
nity; Service; Gatekeeper \\
\hline DOI \\
http://dx.doi.org/10.15294/ \\
kemas.v12i1.3933
\end{tabular}

\begin{abstract}
The percentages of referrals for the first level health facilities visits are coming from the health center (Puskesmas) with $16.85 \%$ at the highest and from the practicing doctors with $12.45 \%$ at the lowest. The aim of the research is to examine the efficiency the promotion, preventive and curative care quality improvement. This study used qualitative exploratory design by case study approach. The collection of data was conducted through field observations, document observation and in-depth interviews. TThe informants consisted of 4 Head of Health Center/Puskesmas, 9 cadres of integrated guiding posts (Pos Pembinaan terpadu /Posbindu) for Non-Communicable Diseases (NCDs), 9 cadres of Integrated Service Post (Pos Pelayanan Terpadu/Posyandu), 33 participants of the National Health Insurance and 23 people from community who have not joined the national health insurance scheme. The results show that mini workshops are held every month in preparing activities with a focus on the causes of most diseases in the previous month. Posyandu may reduce morbidity rate on infants and pregnant women, Posbindu for Non-communicable Diseases can prevent and control non-communicable diseases. Quality of service can improve the perception of the quality of the service and can reduce referrals to hospital.
\end{abstract}

\section{Introduction}

The low quality, equity and affordability of medical care are one of the problems of health development. The increasing health financing aspect will affect the quality, equity and affordability of people to medical services wand affect the quality of human resources. Several factors that lead to an increase the health financing in Indonesia, among others are: 1) the demands for medical services both in quality and quantity are increasing; 2 ) the rate of inflation; 3) changing patterns of infection to chronic diseases; 4) changes in the pattern of doctor-patient relationship because of demands to the doctor ( hospital; 5) the development of medical technology; 6) changes in patterns of health care toward specialist and sub-specialist services.

Bengkulu city is one of the districts/ cities in Bengkulu province. The number of JAMKESMAS participants who go to Puskesmas and are referred to M. Yunus General Hospital in 2009 are about 9.2\%, in 2010 about $10.0 \%$, in 2011 with $9.1 \%$ and in 2011 by $9.8 \%$. The Askes participants who are civil servants in Bengkulu are 182,920 people. From the number, there are 46,490 people who use Puskesmas as first-level medical providers (PPK I) in 2010 with the number of visits of 123,283 people $(265.18 \%)$ and the referral number of 17,157 people (13.92\%). In 2011, there are 40,586 people with the number of visits of $149,487(368.32 \%)$ and the referral number of 20,133 (13.47\%). In 2012, there are 45,960 people with the number of visits 141,876 (308.64\%) and the referral number of 24,822 $(17.49 \%)$. Based on the average percentage of visits in October 2014 to February 2015 in the

\footnotetext{
Correspondece Address:

Campus II University of Muhammadiyah Bengkulu

Jl. Rambutan Lingkar Timur Kota Bengkulu

Email : betrianita@gmail.com
} 
city of Bengkulu, the highest average of $7.79 \%$, and the lowest in Head division of district with an average of $5.39 \%$. The average percentage of referrals from the highest visit in Puskesmas is $16.85 \%$ and the lowest at 12.455 Practice Physicians for the first-level of health facilities Branch Office of Bengkulu. Patients who are admitted to the hospital mostly say that they are authorized to be treated/served at the health center. Puskesmas is still authorized to treat but because of the limitations of medical devices for diagnosis such as Rontgen, Labor, EKG do not exist, they are in difficult situation. Puskesmas as a gatekeeper or controlling the use of participants of the National Health Insurance in Bengkulu can reduce the number of treatment visits to primary health care and hospitals by optimizing the promotion and preventive services.

National health insurance (Jaminan Kesehatan Nasional-JKN) is organized under the National Health Insurance Act No. 24 of 2011 on the Implementation of the Social Security Agency (Badan Penyelenggara Jaminan Sosial-BPJS). The purpose of National Health Insurance is to enable the public to access quality health services. JKN aims to provide basic needs for people in meeting a decent life for each participant and/or family members. Some BPJS organizing principles include cooperation, mandatory participation, contributing fees based on a percentage of wages / income, non-profit management and mandate. The National Health Insurance began in 2014 to achieve Universal Health Coverage gradually.

The catastrophic expenditure among other things is addressed for the treatment of long and expensive non-communicable diseases (NCDs). The non-communicable disease impact from the contribution of risk factors include: 1) the cigarette / tobacco; 2) an unhealthy diet; 3) the substance of alcohol; and 4) the lack of physical activity. Noncommunicable diseases can be prevented by healthy behavior changes. The result of the development of community empowerment conclude that mere medication is not enough to improve public health, therefore, prevention is needed. Those preventive actions are for example vaccination programs and public health campaigns on alcohol abuse and smoking.

The disease prevention and control can be done by empowering the public health sector. Integrated Service Post (Pos Pelayanan Terpadu/Posyandu) is one of the efforts of health-resourced community (UKBM) managed and organized from, by and with the community in the implementation of health development to empower communities and provide convenience for the public in obtaining basic health services and accelerate the reduction in maternal mortality and infant. Some independent efforts done by community to improve health quality are done through some actions namely prevention programs, disease control and disaster-emergency mitigation program of "Desa Siaga". The program implements several program such as (Posyandu), Caring Mother Movement, Nutrition Improvement, hygienic and healthy lifestyle (PHBs), mosquito larvae eradication (PSN), poskesdes and disaster emergencies. Desa Siaga shows a condition where rural communities have the readiness of resources and the ability and willingness to prevent and overcome health problems, disasters and health emergencies independently.

The developing prevention and control of non-communicable diseases is a noncommunicable disease guiding post (Pos Pembinaan Terpadu Penyakit Tidak Menular/ Posbindu PTM). This joint commitment of all elements of society who are concerned about the threat of non-communicable disease is channeled through Posbindu PTM. The development of Posbindu PTM is an integral part of the health care system based on the problems that exist in society and includes promotion as well as preventive and referral patterns. Optimization of primary care to control and streamline the cost of hospitalization, and transportation, effective utilization of primary care can streamline care services.

The function of public health-based efforts (UKBM) as Posyandu and Poskesdes is still limited, $\mathrm{BOK}$ is just a funding for local governments in the implementation of preventive and promotion health efforts to continue, so that local governments have committed in utilizing BOK as effectively as 
possible. The sufficient planning of action (POA) funds is really effective to improve the health of the community, especially the essential programs such as Desa Siaga which has implemented various activities such as Posyandu, Caring Mothers movement, nutrition improvement, and clean and health lifestyle, Mosquito eradication nest, poskesdes and disaster emergencies. Puskesmas can increase the capacity of officers in identifying health problems in the community and developed standard operating procedures (SOPs) in the prevention and promotion health efforts at the health center level.

Based on Rikesdas 2013, healthy and clean life behavior of people is still low. Bengkulu province population who smoke in 2013 is as many as $37 \%$ of the population, members of the household washing their hands as many as $34.5 \%$. This generative disease conditions will impose the implementation of national health insurance if promotion and prevention efforts have not been done. Wrong dietary behavior in Bengkulu Province is still high. The number of population eating less vegetables and fruit age above 10 years in 2007 is as many as $91.4 \%$ and in 2013 , there are $94.4 \%$ who eat less vegetables and fruit and it can cause cancer.

One strategy to improve health development is to empower and increase the role of society, including the business. The communities are given the facilities and guidance in developing a body for the role, given the knowledge and skills to identify problems in their respective areas, to identify, formulate and resolve its problems on a priority basis and the existing potential. In determining priority issues, planning, implementing, monitoring and assessing the activities, people need to be involved from the beginning. Potential community can be explored to the maximum, so that solutions to problems more effectively and able to guarantee the continuity of activities. Primary health care providers in Bengkulu provide services to the general public and participants of the national health insurance, the optimization of the primary service control will be able to streamline the cost of hospitalization, and transportation, effective utilization of primary care can streamline care services.
Based on the description of the background, researchers examine the efficiency of service through the increased role of Puskesmas as a gatekeeper or controlling the participants using the National Health Insurance in Bengkulu by reducing the number of treatment visits to primary care and hospitals.

\section{Method}

This study used qualitative exploratory design under the case study approach. The unit of analysis was conducted in Bengkulu Puskesmas with a focus on the social situation where Puskesmas has the role as gatekeeper. Puskesmas is a health care facility that organizes public health efforts and the first rate efforts of individual health, with more emphasis on promotion and prevention efforts to achieve the highest degree of public health in the working area. Puskesmas is one of the first-level health facilities in collaboration with the Social Security Agency (BPJS) Kesehatan that serves as gatekeeper.

The informants were 4 head of Puskesmas that have the highest number of participants of the National Health Insurance, 9 cadres of Posbindu of Communicable Diseases, 9 cadres of Posyandu, 33 participants of the National Health Insurance and 23 people in community who have not joined the national health insurance scheme. The informants were in charge of activities as the health center or as personal key. Participants of National Health Insurance have not used Puskesmas as the first level medical facilities are the members of Posbindu PTM. This study employed incidental sampling technique to decide the participants of JKN and the public.

The research instruments used interview guidelines, primary data collection through in-depth interviews, focus group discussions (FGD) and direct observation of secondary data collected through observation documents. The collected data were the number of visits and referrals from Puskesmas, Puskesmas planning, Puskesmas staff job descriptions, Puskesmas existing equipment, documents the implementation of GMP and Posbindu PTM to determine what activities were undertaken and the benefits to the community. Observations used the check list to explore 
document and to investigate the measurement and inspection of Puskesmas planning. The interview was conducted to cadres to find out the implementation of GMP and Posbindu PTM. The interviews which were conducted to the public was to know the health benefits by joining Posyandu activities and Posbindu PTM and to know the medical services provided by Puskesmas.

Researchers provided guidance to the cadres for the promotion and prevention efforts to the people who came to Posyandu, Posbindu PTM and Puskesmas. Counseling was aimed to increase knowledge, attitudes and behaviors to prevent disease. Counseling was done for 4 (four) months, at the time of counseling investigators conducted interviews to determine whether during on month they went to Puskesmas and whether they are treated or referred to the hospital.

The test of validity was done by four criteria: credibility, transferability, dependability and conformability. Credibility of this research was ensured through triangulation of sources. Transferability was conducted through writing detailed, clear and systematic reports on the implementation of research, so that it could be trusted and applied in other places. Dependability test was conducted by an audit of the whole process starts researchers in deciding problems / focus, entering the field, specifying the data sources and data analysis, testing the validity and compiling the data in a form of research report. Conformability (certainty) in this study was conducted by examining the results of research associated with each process. At each stage of this research, analysis is carried out toward the research purposes.

Qualitative data analysis consisted of three steps interactive models. The component of data analysis were 1) data reduction, dealing with the selection process, focus, simplification, abstraction and transformation of data that appeared in the note of researchers or transcription; 2) data presentation, dealing with conclusion that could be deduced; 3) conclusion / inference, dealing with that verification studies.

In doing pre-observation, researchers collected before performing a secondary data analysis of the activities in Puskesmas. The purpose of the analysis was to fit/match the available secondary data with the collected data. During the analysis in the field, data was collected through interviews; investigators immediately perform data analysis on the duties and functions of the health center and the results of the interview, so that respondents could be directed accordance with the purpose of research. The study immediately asked back so that answers can be targeted. The collection of data using check list was to adjust or to review data in accordance with the purpose of research.

After collecting the data, researchers analyzed the collected data to determine whether the data had been fit for purpose. Researchers performed data reduction, data presentation and deduction of tentative conclusion. Tentative conclusions would be matched with the purpose of research. To reinforce the results, researchers collected data from other analysis units, the result was the same as the duties and functions of the previous Puskesmas, and then the researchers concluded the results.

Quantitative data analysis was done to see the trend in the number of visits and referrals from month per month for 6 (six) months. The results of interviews with people who visited Posyandu and Posbindu PTM to determine whether during a year they had to be treated in the clinic, and during the treatment, were they referenced or not.

The interpretation of data was compiled by the main tasks and functions of Puskesmas. An ongoing process involved continuous reflection about the data, asking analytical questions, and writing a report throughout the study. The analysis of qualitative and quantitative data was used to make interpretations and to write reports. The analysis of collected interviews and reporting note might eventually be included as a narrative in the final report. The data analysis involved open data collection by asking general questions and analysis of the information provided by the informants. Analytic differences depended on type of strategies which used common procedures and submitted the proposed measures of data analysis. 


\section{Results and Discussion}

The management implementation in four Puskesmas, they have been implemented in accordance with the guidelines and developed in accordance with the conditions. The results of interviews in four Puskesmas can be seen from the following results:

One from four Puskesmas has limited time open enrollment at 7:30 a.m. to 11:00, and three Puskesmas open until the service began 07.30-13.30 according to the working hours.

\begin{abstract}
Mini workshops have been conducted every month with activities to evaluate the activities of previous months and plan activities of the current month. The evaluation results are analyzed to find the cause of the problem and to plan the current month program as well as to find out the cause of most diseases in the previous month (the result of four Puskesmas).
\end{abstract}

Puskesmas have been implementing the program of community-based health efforts (UKBM). Puskesmas have not optimally involved the participation of Head of District, Head of Village, Chair of the Neighborhood (RT) to mobilize communities to participate in the implementation of UKBM like Posyandu, Posbindu PTM, Posyandu for elderly (the result of four Puskesmas).

Cadres have helped to implement $U K B M$ but they do not help to evaluate the implementation of UKBM and report it to the health center and head of village (the result offour Puskesmas).

Puskesmas is as an institution or a work unit serving the district or rural area for improving health services to people. The understanding of the Puskesmas is a functional Health Organization directly under the supervision of both the administrative and technical aspects under Health department of Regency / City (Saputra, 2013)

Puskesmas has the duty and responsibility for health oriented development with the concept of territory. Puskesmas coordinates with the relevant sectors to improve public health among others with schools to improve student health through school health efforts (UKS) or with agriculture sector so that farmers can use pesticides or organic fertilizer properly so it does not cause disease. They also cooperate with trustees of Family Welfare (Pembina Kesejahteraan Keluarga-PKK) districts and villages to build healthy families by going the Posyandu and Posbindu PTM. Puskesmas is held by the principle of areas integrating all available resources such as cross-sector, community leaders, community groups, families and individuals in the working area of Puskesmas. Promotion and prevention programs on health care are important to detect the health problem early, prevent and control diseases that exist in society. Puskesmas implementing promotion and prevention efforts will be able to suppress the rate of illness and the diseases can be controlled and prevented.

Puskesmas management application to perform the duties and functions of implementing health policies is to achieve development goals of health in the working area and to support the realization of healthy districts.

The tasks of Puskesmas are implemented by carrying out the community-based health (UKBM) including: Posyandu, Posts Guidance Integrated Non-Communicable Diseases (Pobindu PTM), counseling Behavior on clean and healthy lifestyle (PHBS), counseling in the effort to improve the health of mothers and infants in Posyandu, extension control of non-communicable diseases in Posbindu and counseling in Puskesmas to patients who are waiting for treatment. According Ayuningtyas (2014), the perceptions of midwifes in Puskesmas who feel that the involvement of employee in Puskesmas is because they are not involved directly in the activities. Meanwhile, the heads of Puskesmas expect that the midwife coordinator should coordinate in advance with the entire midwife in Puskesmas. In addition, some midwifes have the perception that before doing routine and new work, head of health centers must provide advance directives. Meanwhile, according to the heads of Puskesmas, the staffs already know so they do not need to be given direction and guidance in particular. 
The role of Puskesmas is highly dependent on management strategies for undertaking the task goals which provide community empowerment and stakeholder encouragement to reduce morbidity and improve health. According to Dharmawan (2015), supervision from the leaders is one of the factors in the management system to provide assistance and to direct subordinates so that subordinates have the ability to perform the job. Supportive and well-planned supervision is an important factor in the success of health programs, including in terms of recording and reporting to improve data quality of midwife. Supervision from Puskesmas leaders can improve performance of the staffs so that they work better and focus on the target. Septyantie research result (2012) shows that the realization of BOK funds which focuses on health care for the increase (promotion) and prevention (preventive) programs can improve health care coverage and community participation in Nutrition KIA.

Most research on the gatekeeper has focused on health care utilization and costs, while the effects on health outcomes and associated patient receive limited concerns. When considering the gatekeeper, policy makers need to be aware of the limitations and uncertainties. Future research should focus on studying the effects on health outcomes and patient satisfaction in the context of health systems and managed care to ensure a strong recommendation (Garrido, 2011).

The Ottawa Charter identifies three basic strategies for promotion. Health advocacy creates the essential conditions for health, enabling everyone to achieve the full potential of their health, and mediation between the different interests in the community improving health. These strategies are supported by five priority actions of areas as outlined in the Ottawa Charter for health promotion a) building heath public policy, to all sectors and stakeholders levels in order to make the vision of health policy; b) creating supportive environments for health, developing a network of partnerships to support activities that pay attention to the policy; c) Strengthening community action for health through concrete and effective activities to strengthen community activities to achieve better health; d) developing personal skills, improve knowledge and skills of each person to maintain health, recognize the disease and its causes as well as to control and prevent disease; e) reorienting health service, health concerns not only health services but also stakeholders to create policies of health promotion program by empowering people to control and improve the health of individuals. The emergence of new challenges for the field does not negate the relevance of the Ottawa Charter. On the contrary, the Ottawa Charter strengthens the notion for the field of health promotion campaigns. It continues to confirm the vision, action orientation, and support the values that comprise health promotion. Bangkok Charter for sustainability highlights the issue of health promotion focuses on the investment required to meet the health challenges of globalization. WHO global health conference emphasizes the special promotion measures to support the implementation of health promotion strategy and to close the implementation gap. Three gaps identified for the implementation of health promotion areas of concern are: the lack of evidence which is implemented in practice, the lack of evidence the application of health impact in public policy, and the lack of sufficient capacity for health promotion practice in many countries (Potvin, 2011)

Primary health care in Australia is the first level service that provides health services and systems with a trained workforce, consisting of a multi-disciplinary team that is supported by an integrated referral system, giving priority to those most in need; maximizing individual selfreliance, community participation and control, and collaborative partnerships involving other sectors to promote public health.

Puskesmas as a first levels health facilities is very relevant to apply the principles of Public Health Care (PHC) to provide comprehensive services, namely: promotion, preventive and curative programs to maximize individual self-reliance, collaboration and partnership with other sectors for prevention and control of healthcare, support health systems, referral systems and health services. According to Rejeki (2012), community health centers/ Puskesmas as a companion implement Desa Siaga Program to provide good facilitation techniques that can lead active Desa Siaga. However, the facilitation 
is done in the development of rural Puskesmas has not yet realized community development, but more towards the social mobilization. Puskesmas needs to seek techniques to be able to realize the implementation of the community empowerment of Posbindu PTM to achieve early detection, prevention and control of NCDs.

Puskesmas can perform individual services according to the Clinical Practice Guidelines for doctors in Primary Health Care Facilities including the guidelines for the management of the disease in primary care based on the following criteria: a) the disease prevalence is high; b) the disease is a high risk; and c) a disease requires high finance. Puskesmas that serves as an organizer of public health efforts and the efforts of individual health can play an important role in early detection, prevention and control the disease in the community in their working area. This health center functions in accordance with the Declaration of Alma-ata and functions of primary health care facilities in many countries. Basic health services according to the declaration of Alma-Ata (Gillam, 2008), are: a) reflecting and evolving from the economic, socio-cultural characteristics of the country and society based on the application of relevant research results, social services, biomedical and health and wellness experience community; b) discussing the main health problems in the community, providing promotion, preventive, curative and rehabilitative services; c) involving at least: education concerning on prevailing health problems, methods of prevention and control; promotion of proper food and nutrition; an adequate supply of clean water and basic sanitation; maternal and child health services, including family planning; immunization toward the major infectious diseases; prevention and control of locally endemic diseases; right treatment of diseases and injuries; provision of essential drugs; d) involving, in addition to the health sector, all related sectors and aspects of national and community development, especially in agriculture, animal husbandry, food, industry, education, housing, public works, communications and other sectors; and requires the coordinated efforts of all those sectors; e) providing the promotion for the community on the individual maximum independence and participation in the planning, organization, operation and control of primary health care, making use of all the resources of local, national and other available, purpose developed through appropriate education the ability of communities to participate; f) must be supported by an integrated, functional and mutually supportive referral systems, leading to improvement of comprehensive health care, and giving priority to those most in need; g) depending on the local level and referral, health workers, including doctors, nurses, midwives, nurses and community workers that apply, as well as traditional practitioners as needed, trained socially and technically to work as a health team and to respond to public health needs; h) in need and promote community, individual self-reliance and participation of cross-sectorial focus and involvement of the private sector.

Puskesmas which is one of the firstlevel health facilities in collaboration with the Social Security Agency (BPJS) Kesehatan plays an important role as a gate keeper for the function of carrying out the individual health and public health efforts. Puskesmas has many program types and the amount of power that can exercise the functions of the Puskesmas. Gate keeping system is to give doctors a lot of responsibility to make sure to refer patients to more specialized services when it is needed and at the same time regulate the ability to recognize when they themselves can provide adequate treatment (Pedersen, 2012).

Puskesmas as a first-level health facility (FKTP)/primary provide services before the first or services referred to hospital. Puskesmas provides services to the public / participants of the National Health Insurance are suffering from infectious diseases and non-communicable diseases. Indonesia faces some challenges for the effective implementation of the Universal Health Coverage (UHC) in order to extend the breadth, height, and peace of coverage, particularly in addressing the condition of noncommunicable diseases which are generally chronic in nature and require management of patient case carefully from time to time, and the most cost effective targeted at primary care level (World Bank, 2014). 
Primary care serves as the basis of a strong health system. However, it has long been ignored in the United States, and the imbalance between primary care and specialist services exists there. The purpose of this paper is to identify evidence of primary care in the United States and internationally with a focus on the importance of primary care that is effective in providing quality health care, improving health outcomes and reducing inequalities. Developing countries, primary care has been shown to be associated with increased access to health care, better health outcomes, and decrease hospitalization and use of emergency room visits. Primary care can also help diminishing the negative effects of adverse economic conditions on health (Shi L, 2012).

The function of first contact Puskesmas is to ensure the continuity of participant visits whenever health problems occur so that the handling of the disease can run optimally. Besides, Puskesmas must provide comprehensive services mainly for health promotion and prevention, coordinate with health care providers in order to give health services to participants according to their needs. The doctors are on duty to function as regulators of services (care manager). Policy focuses on the issue of the readiness of the supply side of the perspective of assessing the depth of the Universal Health Coverage (UHC) in Indonesia, especially in rural and remote areas where most of the population is poor and nearly poor live and with a focus on non-communicable diseases include diabetes mellitus (DM ), chronic cardiovascular conditions, and chronic respiratory conditions at the primary level community care ( $\mathrm{PHC}$ ) in Indonesia.

Using various sources of information including analysis of Rifaskes facility census in 2011, it shows that the ability of Indonesian health system to provide effective coverage for the non-communicable diseases throughout Indonesia is still lacking especially for the treatment of non-communicable diseases. Therefore, it is required to have special efforts to prevent and control non-communicable diseases in order not to burden the National Health Insurance program (World Bank, 2014). Health care for non-communicable diseases at the primary health care providers in Puskesmas must be optimized, especially in promotion and preventive programs to prevent and control non-communicable diseases. Puskesmas must optimize human resources and other resources to carry out the duties and functions of the health center so that it can act as a gatekeeper in order not to burden the National Health Insurance. Core functions of primary care and public health is significantly very spacious (assessing the health needs of the population, promoting and supporting healthy lifestyles and behavior, supporting the growth and development through the life cycle and promoting health and other vulnerable groups). They offer the opportunity to deepen the partnership between primary care and population health. Without a mechanism for the development of a truly integrated and jointly own plans and programs, primary care and public health are unlikely to be able to address the fundamental challenges in preventing chronic diseases and reduce health inequities. It is widely recognized that addressing health inequalities in Australia requires action to address the social determinants at all levels of the health sector in collaboration with the government, private sector, community groups (Mark, 2012).

Health promotion is a social and political process that is comprehensive, not only necessary actions directed at strengthening the skills and abilities of individuals, but also action directed changes in the social, environmental and health promotion so as to alleviate the impact on the economy. Public and the individual health is a process that allows people to increase control over the determinants of health and thereby improve their health. Participation is essential to sustain health promotion action. The Ottawa Charter identifies three basic strategies for promotion. Health advocacy creates the conditions essential for health, enabling everyone to achieve the full potential of their health, and mediation between different interests within the community to improve health. Public health with regard to disease prevention and control at the population level through an organized effort that includes organizations, public, private and individual. Contribution to public health comes 
from systems outside the formal health care system, and the potential for cross-sectorial contribution to public health is increasingly recognized worldwide. The government's role is very important in influencing the health of the population which is not limited in the health sector but also by the various sectors outside the health system (Lakshminarayanan, 2011).

Desa Siaga is a condition of rural communities which has the readiness of resources and the ability and willingness to prevent and overcome health problems, disasters and health emergencies independently. Puskesmas as a mentoring implementation of Desa Siaga has given supplies good facilitation techniques that can lead active participation of Desa Siaga. The facilitation done by Puskesmas has not realized community development, but more towards the social mobilization (Sri, 2012). The change or innovation policy with adequate socialization needs to be followed up. Socialization should be done in order to concede equality and harmony in making of a new policy such as rural / village / RW Siaga. To be more easily understood by the local government, policies must be associated with the policy of community empowerment, especially the strengthening of the capacity of villages and sub-level governments need to be integrated in the framework of the Ministry at the national level within the framework of the development in strengthening of regional autonomy (Darmawan, 2012).

The supporting and hindering actors to increase public participation in Manado and Palangkaraya show that basically the supporting and hindering factors are as follows: a) local government leaders such as Head of Village; b) religious and community leaders; c) Public Health Board / Puskesmas (PHC); d) community; e) potential Organizations such as the PKK, BPD, NGOs, Youth, Religious Institutions and Custom Agency. Posyandu is one of the activities of primary health care by the volunteer health workers to target infants, toddlers, pregnant women and couples of childbearing age. Especially for Posyandu cadres, it is necessary to improve the skills of advocacy and negotiation periodically thus more confident in carrying out development activities.
Integrated Development of NonCommunicable Diseases Post (Posbindu PTM) is an community empowerment organization to control, prevent and control non-communicable diseases. Puskesmas has implemented Posbindu PTM with the following results:

Puskesmas has implemented Coaching Integrated Post for non-communicable diseases (Posbindu PTM) which is assisted by cadres. Puskesmas as an executor has not optimally involved the Head of district, Head of village, Chair of the Neighborhood (RT) to mobilize the community to participate in the implementation of Posbindu PTM. The cadres have not carried out the evaluation of Posbindu PTM which is reported to Puskesmas and head of village to expect the feedback (results of four Puskesmas).

Posbindu PTM in the region of four Puskesmas is held every month in which the schedule is established by Puskesmas. The implementation of Posbindu PTM is informed through the loudspeakers of mosques and word of mouth. Posbindu program is started with registration and then followed by measurement of weight, abdominal circumference, moisture content, fat content and blood sugar, uric acid, cholesterol checks (the interview three PHC).

Posbindu PTM activity begins with socialization and implementation of measurement and inspection (result from one Puskesmas).

The activities of the last medical examination and drug delivery to members who indicated a particular illness are referred to Puskesmas. Posbindu PTM held at Puskesmas yard is directly referred for treatment to Puskesmas (Puskesmas one result).

Monitoring and evaluation in general has not been implemented, there is only a report from the health center to the Department of Health (outcome four Puskesmas).

Posbindu PTM is a form of public 
participation in the activities of early detection, monitoring and follow-up of risk factors NCDs independently and continuously. This activity is developed as a form of early warning because almost all of the risk factors of noncommunicable diseases are asymptomatic. The general objectives of Posbindu PTM are to create programs of prevention and control of non-communicable disease risk factors for community-based participation through an integrated, routine and periodic program. The specific objective include: 1) implementation of early detection of risk factors for NCDs; 2) monitoring the implementation of noncommunicable disease risk factors; 3) the implementation of the follow-up of early risk factors for NCDs. The goals in the administration of Posbindu PTM are divided into 3 groups of specific objectives, goals and objectives of the support. The approach to the three goals should be done in an integrated manner during the implementation process.

Posbindu PTM activities carried out by the people in the city of Bengkulu based on research by observing each activity include: The Interviews to gather information about the history of risk factors for non-communicable diseases in the family and the participant, physical activity, smoking, eating vegetables and fruit as well as other information needed to identify the health problems associated with the occurrence of NCDs. This activity is done when the first visit and periodically once a month after participants are registered.

Based on the results of theimplementation of Posbindu PTM, the interview of cadres to members Posbindu PTM new about family history of disease, individuals, smoking habit, the habit of eating vegetables, fruits and other activities. These results are recorded in the medical record of each participant. These results would be the source of material when an individual go for counseling.

The measurement abdominal circumference and body weight is carried out by Kader. The measurement of blood pressure, tension, simple lung function, blood sugar, cholesterol and triglycerides is carried out by health personnel. Activity counseling and education is conducted by every
Posbindu PTM. Based on the results, the examination is done directly by the medical officer and there are referred to the Puskesmas.

Posbindu PTM referral system supports comprehensive health care for people up to the highest level of services. The benefit of Posbindu PTM is to serve as a community-based health efforts in which the targets / clients and empowered society should participate actively in the activities and health programs. From the implementation of Posbindu PTM from registration until being registered as members and finally they go home will be able to help Puskesmas detecting non-communicable diseases such as diabetes mellitus (DM), high blood pressure, cancer and others who continued with treatment can prevent and control diseases that could reduce the level pain.

The model of community empowerment can be seen from the four domains of development organizations which are formed based on the opinions and perceptions of community members: 1) activation of the community; 2) competence in solving problems on their own; 3) ability of program management and 4) creation of supporting environment (Kasmel, 2011). Health promotion is most often delivered through a top-down program which is controlled by government agencies or non-governmental organizations (NGOs) funded by the government. Government policy (and resources) which sets the agenda of health promotion difficult starts when it is not met community concerns. The dependence on government funding of health promotion has contributed to the dominance of the top-down style of programming. According to Pratamawati (2012), a proactive health paradigm as a model for health development is expected to create self-sufficient communities in maintaining health through greater awareness on the importance of health promotion and preventive action. Dengue fever prevention program in this paradigm prefers the approach of promotion and preventive efforts including capacity building/health volunteers as the main entrance to improve understanding of the epidemiology of this deadly disease. 
Based on the interview to some people who do not utilize health centers as first-level health facility says:

I am not sick because it has become a member of Posbindu PTM and follow regularly every month. In Posbindu PTM measurement, the blood tests and health area checked so that I can stay healthy.

Based on the above explanation, concept development will look at the role of stakeholders, the public, and cadres in identifying needs based on concerns of the community as a method of application to construct a model of empowerment Posbindu PTM in the early detection, prevention and control of non-communicable diseases can prove reduce morbidity.

The implementation of Posyandu has been conducted in every Puskesmas. The staffs are more proactive in reminding cadres for the implementation of Posyandu. Based on the results of interviews with health cadres in four health centers, the result is as follows:

Cadres need to get refreshing training because they have not received any training for quite long time. The role of health care staffs in reminding the readiness of Posyandu cadres for the next day is very helpful (the results of four Posyandu.).

The support from Head of district, Head of village, PKK, Chairman of $R T$ rarely mobilize the community to come to Posyandu. The implementation funding of Posyandu is the donation from $B K K B N$ as one of the resources that can move Posyandu (results from one Puskesmas).

Puskesmas staffs provide counseling or examination, registration, weighing and other measurements done by cadres (results from four Puskesmas)

Posyandu is a form of community participation in the health sector which is managed by cadres. The target is the whole community. Posyandu is one of UKBM managed and organized from, by and for the community. In an effort to decrease the morbidity and mortality of infants and toddlers, birth rate in order to improve public health which has developed an approach to alignment which in its implementation at the village level is done through Posyandu.

The targets of Posyandu are: infants, toddlers, pregnant women, new mothers, postpartum and breastfeeding mothers and spouses of fertile age. The objectives of Posyandu are: a) to reduce morbidity of mothers and children; b) to accelerate the reduction of infant mortality rate (IMR), children under five and the birth rate; c) to accelerate the reduction of maternal mortality (MMR), pregnant women and postpartum mothers; d) to accelerate the receipt of Small Happy and Prosperous Family Norms (NKKBS); e) to enhance the ability of communities to develop health activities and other activities that support as needed; f) to increase the coverage of health services.

The services held in Posyandu are for babies and young children include: monthly weighing and nutrition and health counseling, provision of nutrition help package, immunization and monitoring of cases of flaccid paralysis and early detection of growth and development, disease identification, simple treatment and referral especially for diarrhea, inflammation of the lungs (pneumonia). pregnant mother include: prenatal care, feeding (PMT) for maternal malnutrition or chronic energy deficiency (CED), the provision of iron tablet and iodine capsule and counseling about nutrition, maternal health and safe delivery planning. Mother postpartum / breastfeeding include: vitamin A supplementation, supplementary feeding (PMT), postpartum care for mother and baby, iron tablet supplementation, family planning services, and IEC/ counseling.

Posyandu developed in the initiative of President Suharto in 1984. Posyandu has been the pride of the people. Every month people flock to the Posyandu managed by 
community-based, led by cadres / health volunteers who have received training from the health department, providing health guidelines for pregnant women and nursing mothers. In addition, Posyandu also gives vaccinations and food supplements to infants and toddlers. Posyandu serves as early detection of cases of malnutrition and malnutrition in infants and toddlers. The success of Posyandu makes some countries adopt the concept of Posyandu and instead, they are able to develop better than in Indonesia today. Posyandu participation shown by the effect of mentoring and training learning organization (LO) to the cadres except in terms of the number registered in Posyandu cadres. The influence on mothers is reflected in different proportions, as well as on the health service in Posyandu. The significant implementation can be seen from the monitoring of children growth between the intervention areas with control areas (Aminuddin, 2011).

The results of research from Pratama (2007), still shows low ratings for the role of participation (PSM) in accelerated of MMR and IMR decline in the form to provide counseling, socialization and education to overcome the concept of " 4 over and 3 too late" through various activities such as teaching, social gathering, consultation village and church service. PSM activities are more in contributing personnel, funds, facilities in the management of the PSM such as Posyandu activities, village medicine posts and Toga. PSM is concrete evidence by the public to the health sector, especially in efforts to reduce maternal and infant mortality.

The benefits of Posyandu according to Shiffman (2007), in the article "Generating Political Priority for Maternal Mortality Reduction in 5 Developing Countries" published in the American Journal of Public Health shows the success of the New Order government to reduce maternal and infant mortality and is encouraged by what he call as a "political entrepreneurship". This means that the President is the leader of the campaign, increases the budget to reduce maternal and child mortality, and mobilizes provincial government and district / city to pay attention to the same problem. In the New Order era, Puskesmas and Posyandu become the spearhead the implementation of the program at the same time in the field of health. Puskesmas and Posyandu services are spread to remote villages reduce infant mortality, controlling the spread of infectious diseases, and improve public health conditions.

In particular, Posyandu becomes the of information dissemination about the importance of family planning and health services before and after childbirth. Posyandu teaches community on how to manage nutrition, clean clothes, and healthy house (Shiffman, 2007). Hope is always there for new Health Minister to make a breakthrough to achieve the MDG targets and prepare the various efforts so that the people can live healthy and make efforts in early detection of diseases. At the global level, a health problem has become a Global Health Diplomacy. The concept of community health development refers to a healthy life without pain.

Posyandu absolutely needs to be revitalized due to the following points which constitute the conception and thought at the time to develop Posyandu. Firstly, Posyandu helps citizens to remain healthy so that the revenue could be used for other needs. Reducing the dependency of citizens to the National Health Insurance will save the use of the state budget. Secondly, the role of Posyandu is crucial when the availability of doctors is still inadequate. Although the number is increasing, general practitioners do not spread out evenly. Thirdly, Posyandu reduces excessive dependence of society to the use of medicines.

Posyandu has demonstrated benefits to the new era and can reduce morbidity and mortality of mothers and children. Improving health makes people healthy without pain. The success of Posyandu could reduce spending on health care both by society and the state. Toddler weighing done by Posyandu aims to monitor developments, so that parents know what to do if there is no increase in weight. Weight monitoring also aims to review the conditions of children under five over the last month, the disease symptoms and nutrition needs for the infants. Immunization is an attempt to prevent diseases that can be prevented by immunization. Posyandu can also provide guidance and counseling to maintain 
health of infants and mothers to stay healthy.

\section{Conclusion}

Puskesmas can be divided into two categories namely: first, the center of health care promotion and prevention targeting communities and individuals; second, health centers as primary individual health care center where the role of Puskesmas as gatekeeper. The integrated couching post non-communicable diseases (Posbindu PTM) is a form of public participation in the activities of early detection, monitoring and follow-up of risk factors NCDs independently and continuously. Posyandu actively plays as role of community participation in the health sector which is managed by health cadres targeting the whole community.

Posyandu as the first level of health care providers (FKTP) has the function of improving public health through promotion, preventive and curative community empowerment which will be able to decrease the number of hospital visits and referrals to hospitals. Posyandu must optimize the implementation and scope so that Posyandu and Posbindu PTM can detect, prevent and control the disease from spreading.

\section{Acknoledgement}

My highest gratitude is addressed to Kopertis Region II which has funded this research through DIPA Directorate of Research and Community Services, Directorate General of Higher2015. I also extend my big appreciation for the Chief of Medical Officer of Bengkulu, Head of Puskesmas Bengkulu City, Posyandu and Posbindu PTM Cadres who are willing to become informants in this study.

\section{References}

Aminuddin, Zulkifli A., Djafar N. 2011. Peningkatan Peran Posyandu Partisipatif melalui Pendampingan dan Pelatihan Upaya Pemantauan Pertumbuhan dan Masalah Gizi Balita di Bone, Sulawesi Selatan. Jurnal Kesehatan Masyarakat Nasional, 5(5).

Ayuningtyas, D, Rezeki, SP.,. 2014.Kualitas Lingkungan Kerja dan inerja Bidan Puskesmas dalam Pelayanan Kesehatan Ibu. Kesmas. Jurnal Kesehatan Masyarakat Nasional, 8 (6): 265-271.

Darmawan, ES,. 2012. Mengukur Tingkat Pemberdayaan Masyarakat dalam Sektor Kesehatan. Jakarta. Kesmas. Jurnal Kesehatan
Masyarakat, 7(2).

Dharmawan, Y., Wigati, PA., Dwijayanti, F. 2015. Kinerja Petugas Dalam Pencatatan dan Pelaporan PWS KIA di Puskesmas Duren. Jurnal Kesehatan Masyarakat, 10(2): 210217.

Garrido, MV., Zentner, Buse, R. 2011. The effects of gate keeping: A systematic review of the literature. Scandinavian Journal of Primary Health Care, 29: 28-38.

Gillam, S. 2008. Is the declaration of Alma Ata still relevant to primary health care?. BMJ 336

Kasmel, A., Andersen, PT. 2011. Measurement of Community Empowerment in Three Community Programs in Rapla (Estonia). Int. J. Environ. Res. Public Health, 8, 799-817

Lakshminarayanan, S. 2011. Role of government in public health: Current scenario in India and future scope. Journal of Family and Community Medicine, Vol. 18 (1) : 26-30.

Mark, F., Harris, MF., Harris, E. 2012. Partnerships between primary healthcare and population health: preventing chronic disease in Australia. London. Journal of Primary Care, 4:133-7

Pedersen, KM., Andersen, JS., Søndergaard, J. 2012. General Practice and Primary Health Care in Denmark. JABFM, 25: 34-38.

Potvin, L., Jones CM. 2011. Twenty-five Years After the Ottawa Charter: The Critical Role of Health Promotion for Public Health. Can $J$ Public Health, 102(4): 244-48.

Pratamawati, DA. 2012. Peran Juru Pantau Jentik dalam Sistem Kewaspadaan Dini Demam Berdarah Dengue di Indonesia. Kesmas, Jurnal Kesehatan Masyarakat Nasional, 6 (6) : 243-248

Rejeki, LS., Hasanbasri, M., Sanjaya, GY. 2012. Peran Puskesmas Dalam Pengembangan Desa Siaga di Kabupaten Bantul. Jurnal Kebijakan Kesehatan Indonesia, 1: 154-160.

Saputra, RF. 2013. Studi Tetang Pelaksanaan Program Jaminan Kesehatan Daerah (Jamkesda) di Puskesmas Sidomulyo Kecamatan Samarinda Ilir Kota Samarinda. eJournal Administrasi Negara, 1(1): 41-55.

Septyantie, UP., Cahyadin, M. 2013. Hubungan Antara Realisasi Dana Bantuan Operasional Kesehatan Dengan Indikator Gizi KIA di Kabupaten/Kota Provinsi Jawa Tengah Tahun 2012. Jurnal Kebijakan Kesehatan, 2 (4): 215-221.

Shi L, 2012. The Impact of Primary Care: A Focused Review Hindawi Publishing Corporation Scientica. Volume 2012, Article ID 432892, 22 pages http://dx.doi. 
org/10.6064/2012/432892

Shiffman, J. 2007. Generating Political Priority for Maternal Mortality Reduction in 5 Developing Countries.Framing Health Matters, Peer Reviewed American Journal of Public Health, 97 (5).

Sri, LR, Hasanbasri M., Yoki, GS. 2012. Peran
Puskesmas dalam Pengembangan Desa Siaga Di Kabupaten Bantul. Jurnal Kebijakan Kesehatan Indonesia, $\quad 1$ (3): 154-160

World Bank. 2014. Supple Side Readiness for Universal Health Coverage : Assessing the Depth of Coverage for Non-Communicable Diseases in Indonesia. www.worldbank.org. 